\title{
Improvement on the Initiator and Causes of Current "Piercing the Corporate Veil" System
}

\author{
Sui He \\ Law Department of Graduate School of CASS
}

\begin{abstract}
In the wake of cancellation of the minimum corporate registered capital by Chinese Government, the smallmicro private enterprises will witness a drastic growth. Under this circumstance, after comparing "piercing the corporate veil" system with foreign countries-especially the U.S.-we can draw some lessons. Pertinent corrective actions shall be carried out for the purpose of avoiding abusing of the "Piercing the Corporate Veil" system. For my part, initiators are recommended to be expanded to corporate staff and environmental public interest litigation subjects, and the causes for initiation should be maintaining of their own interests or the corporate interests and maintaining of public interests or non-specific group interests. So we can partly perfect this important regulation to serve the rapid growth of economy.
\end{abstract}

Keywords-disregard of corporate personality; initiator; legal causes; public interests

\section{INTRODUCTION}

China, on the Executive Meeting of State Council determined that the restriction of minimum corporate registered capital would be repealed. As a result, two obvious consequences will appear. First, due to cancellation of capital limit, the folk venture capital will be released, and the number of enterprises (especial small-micro private enterprises) will witness a rapid growth; in the wake of this, some of pollyanna may ignore applicable laws and regulations to rush hastily into danger, damaging or abusing independent corporate status (especially one man company), thus causing numerous "Piercing the Corporate Veil" cases; second, introduction of new policies. For facilitating market regulation and control, the State Administration for Industry and Commerce will improve applicable policies and legal systems. In this case, it is recommended to learn from foreign experience while considering China's actual conditions. Therefore, in this stage, applicable laws and regulation will be subject to frequent changes. At present, pertinent to cancellation of minimum registered capital by the State Council of China, the existing policies and regulations must be improved and supplemented for adjustment, and implementation of new policies requires support from the improved systems. The State Administration for Industry and Commerce is to establish the mentoring strategy of "lenient entry, stringent exit" and increase "breakcredit cost" to warn against enterprises. The Author will give analysis and exanimation based on current issues and put forward adjustment methods.

\section{SIMPLIFICATION OF INITIATOR AND CIRCUMSTANCE FOR INITIATION}

At present, "piercing the corporate veil" cases are concentrated on four aspects, i.e. hotchpot, obvious asset shortage, fraud or misconduct, excessive control. Initiators are almost creditors and the damaged are almost the interests of creditors. Bases for claim right of lawsuit are concentrated on infringement obligation ( 7 cases), contractual obligation (68 cases) and legal causes (27 cases) [1].

In "piercing the corporate veil" lawsuits initiated in China, plaintiffs are almost creditors of the defendants' companies but few other initiators, and causes are almost damages to creditors' interests but few other causes. In addition, the opinions given in relevant newspapers by the Supreme People's Court also embody that this system pays much attention to protection of creditor's interests. It considers that "when corporate personality denying principle applies, creditors who are damaged due to abuse of corporate personality may be entitled to legal remedies by pursuing the legal responsibilities of the person who abuses corporate personality. [2]" However, during juridical practice in China, new circumstances requiring to be remedied have appeared. With respect to the subject for remedy, what to be remedied in new Company Law is almost the creditor's interest, however, when corporate personality denying principle is established, it is being noted that corporate may use its personality to damage public interest in the form of disturbing market order or damaging consumer's interests. Until now, it is very common to use independent corporate personality to damage labor's rights or even to evade taxes [3]. With the rapid development of economic society, corporate development will be further promoted because the limit on minimum registered capital is being cancelled gradually by the nation and corporate annual inspection will also be cancelled. New or existing legal damage cases may increase. Meanwhile, with the complication of legal relationship and popularization of legal knowledge in public, new understanding of law will be developed. Cases about damaging public interest and the interest of other non-creditors have involved many other aspects among which environmental tort is obvious. Environmental disruption by enterprises affects public interest to a great extent. It not only involves the simple debtor-creditor relationship but also further involves public interest litigation and other unsound legal proceedings [4]. In addition, some scholars have tried discussing the application of "piercing the corporate veil" in other fields will be more and more. Therefore, it is a necessary action to properly increase the circumstances 
of initiating "piercing the corporate veil" and gradually expand other initiating subjects.

\section{APPROPRIATE EXPANSION OF INITIATING SUBJECT AND INITIATING CAUSES}

Some scholars pointed that it is not mature to follow British and America to expand initiating subject and initiating causes at present, and thought that the history of Disregard of Corporate Personality System in China is too short to apply widely. They suggested adopting such strategies as progressively and gradually expanding its application [5]. And I also think that the probability of "piercing the corporate veil" in China is higher than that of British and America. One reason may be that judges may have a preconceived judgment and the second reason is there are inconsistencies or even loopholes among standards and specifications with respect to the application of Disregard of Corporate Personality System because it is just in a start-up phase in China. However, I think it is necessary to appropriately expand the following two kinds of initiating subjects and initiating causes.

First, shareholders of a company may apply to the court for "piercing the corporate veil" for the reason that the controlling shareholder of the company may damage the company's benefits or in the name of the company damage the creditor's benefits.

There are two advantages: first, the initiator will not only be limited to the creditor of a company but is expanded to the shareholder of the company, or even the personnel related to business of the company, including financial staff, minority shareholders, independent director, supervisor, etc. Second, the initiating causes may be protecting the legal rights of the company, avoiding applying "piercing the corporate veil" by creditors, and the initiator' intent for avoiding his interest being damaged because he worries about that he may take a risk of assuming joint responsibility due to the behavior of controlling shareholders or major shareholder. Such cases have occurred in foreign countries. Companies conducting internal supervision can protect not only creditors' benefits but also their shareholder's benefit or even companies' benefits, so as to avoid bankruptcy or other disadvantage consequences.

Such "piercing the corporate veil" cases have two obvious advantages. First, no matter who submits the application, such "piercing" cases may bring benefits to the person, company and creditor, effectively avoid assuming joint liabilities by irrelevant shareholders, limit controlling shareholder's behaviors, and provide convenience for creditor's subsequent litigious activities. Second, such lawsuit can completely avoid corporate veil being pierced. It just involves "prying into the corporate veil", i.e. the court only needs to make clear of the governance structure and staff composition of the company so as to identify attribution of liability in the future. This method is used to decide some cases in British Company Law. In this case, once the court conducts investigation, preventive effect will be brought, and the involved person of the company will have some time to actively assume the liabilities to avoid "piercing the corporate veil", so as to effectively avoid creditor's loss.
Second, properly pursue the liabilities of the company involving environmental tort, i.e. if a company discharges quantities of pollutants and damages the public benefits, any enterprises closely related to it shall assume the joint liabilities.

Responsibility addition in above sentence is due to the following two considerations. First, environment problems and infringement issues at present are getting worse, and most of those pollution discharge enterprises involve group companies or large industry enterprises with both financial and technical strength. Major controlling shareholders of such enterprises often indulge over-discharge for private interests. Besides, when it involves discharge responsibility, they are likely to blame it on their subsidiaries and apply for bankruptcy liquidation after fund transference, based on the independent personality of their enterprises as a legal person. Therefore, they can disassociate themselves from their subsidiaries so as to avoid responsibilities, and even discharge pollutant through their subsidiaries based on such personality and limited liability. Second, Chinese environment public interest litigation has been going through series of amendment and reformation, and perfection of public interest litigation on procedural law has been promoting as relevant practice goes forward. For example, the latest progress is about amendment to Environmental Protection Law of the People's Republic of China (Draft). According to the Draft, environment public interest litigation qualification is limited, and litigation parties are required to be national social organizations that are registered with the Ministry of Civil Affairs under the State Council, have engaged in environmental protection and public interest activities for a successive period of five years and have a sound reputation. So, relevant qualification requirements are still critical. However, in local practice, procuratorial organs, environmental protection organizations and other social groups have been gradually allowed to initiate environment public interest litigation, as stated in Opinions on Establishing Environmental Protection Implementation and Coordination Mechanism published by intermediate court, procuratorate, public security bureau, and environmental protection bureau of Kunming City [6], Yunnan Province. Thus, it is necessary to bring new initiation subjects to the system of "Piercing the Corporate Veil" and to add new initiation causes (environmental infringement) based on above situation, in order to coordinate with procedural laws and to indirectly coordinate with the establishment and perfection of public interest litigation system. Meanwhile, relevant case laws and application principles have already been developed with respect to application of "Piercing the Corporate Veil" in environmental infringement cases, and they worth reference and perfection by Chinese lawmakers and decision-makers.

The Hempel case accepted and judged by Norwegian Supreme Court involves application of the principle "Piercing the Corporate Veil" under corporation law and issues of damage liability for environmental infringement under environmental law [7]. In this case, it involves whether a parent company named Hempel shall bear damage liability for pollution discharge by its subsidiaries. As company Hempel owns $100 \%$ of shares in its subsidiary A, it shall bear damage liability for pollution discharge by its wholly-owned subsidiary A before being purchased by Hempel. However, Hempel chose 
to avoid such liability by transferring original property of subsidiary A to a newly established subsidiary.

During the trial at Norwegian Supreme Court, certain disputes had arose on whether the Court might judge "piercing the parent corporate veil" by referring to section 51 of "Pollution Control Act" (i.e., Norwegian Environmental Law) [8]. Regulations under environmental law cannot constitute legal basis of "Piercing the Corporate Veil"; however, the Court still relied on the said section 51 as judgment criteria. It held that based on the consideration of social public interest, there must be a party to bear responsibilities when it comes to environmental damage liability, in order to further reach a goal, i.e., "material social public interest may constitute a basis of 'Piercing the Corporate Veil' in certain circumstances", and that "environmental protection must cover all fields in order to keep a stable development state". Therefore, the Court finally judged that "Subject to section 51 of Pollution Control Act, all parent companies shall bear responsibilities for damage caused by pollution discharge by their subsidiary or subsidiaries", and no matter whether such parent companies themselves had a fault. Accordingly, it is a liable method to perfect application of environmental infringement in China in "Piercing the Corporate Veil" based on this case.

Moreover, as a transition, there is one subject worth attention beside above two, i.e., subject of other public interest litigation except on environmental issues. But at the present stage, it is still very difficult for such subject to initiate other public interest litigation. First, success of such litigation is extremely limited. For instance, the first public interest litigation case has presently been initiated by a consumer against a tobacco company for misleading promotion. But the consumer failed the case in the first trial. It is hard to add such initiators, as public interest litigation itself still faces much obstruction. Second, current cases of "Piercing the Corporate Veil" in China still seldom involve public interest litigation other than on environmental issues. It requires more theoretical evidences and practical experience to add initiators of such litigation

\section{CONCLUSION}

When the government gradually relaxes the minimum registered capital of companies, many new companies will be established; private capital will be fully released; and number of small-micro enterprises may rocket as well. Under such situation, authorities need to not only strengthen monitoring measures of "lenient entry, stringent exit", but also use improved and perfected supporting measures.

It is especially important to appropriately improve such system in the aspect of corporation law, and in consideration of various issues of "Piercing the Corporate Veil" system in practice and important role of such system in Chinese economic life. Future development of Chinese corporation law will be surely more favorable for enterprise vitality and economic growth, but appropriately combining certain provisions is still necessary. In the writer's opinion, it is proper to perfect the following for "Piercing the Corporate Veil" system:
- Appropriately expand initiators. It will bring mutual reinforcement if the addition of new initiators can coordinate with development of current environment public interest litigations. Besides, adding internal personnel of enterprises as litigation subjects and defining their litigation status, helps to realize overall consideration as it enables "Piercing the Corporate Veil" to serve not only for creditors, but also for interest of the public or non-specific subjects.

- Bring cases tried by grass-root court to intermediate court for review through second trial or retrial, in order to make sure that such cases are prudently settled without misuse.

- $\quad$ Establish a new understanding of such system, learn from advanced foreign experience at a right time and in a proper way, and consider various factors based on present Chinese conditions, to finally form a system applicable to China.

The system of "Piercing the Corporate Veil" comes from America, and has not been abolished during the long-term development and practice. Likewise, Germany, Japan and Britain all have their own unique judicial experience. Now, China has seen a rapid economic and social development. Application of such system, on the one hand, tests the theoretical quality of Chinese judicial personnel; on the other hand, it guarantees overall social interest.

\section{REFERENCES}

[1] Statistical results cited here come from PKULAW DATABASE.

[2] Jin Jianfeng, a judge of China's Supreme People's Court: Disregard of Corporate Personality Strengthens the Protection of Creditors, China Securities Journal, April 22, 2006, Page A07.

[3] Refer to Sun Liting: Extraterritorial Legislation Research on Disregard of Corporate Personality and System Establishment in China, Jianghuai Tribune, 2013 (3), P111.

[4] Refer to Wang Zhen: Application of Disregard System of Corporate Personality in Tax Law, International Taxation in China, 2007 (8), P6064.

[5] Huang Hui, An Empirical Study on the Veil-piercing System in China, Chinese Journal of Law, 2012, Volume 1, P14. The author worries that if it is applied to other aspects, it may cause the abuse of disregard of corporate personality system.

[6] In the writer's opinion, such subjects may also be the subjects of public interest litigation in China so as to correspond to such litigations and let public interest litigations lead the trial of "Piercing the Corporate Veil" cases. In the course of particular litigation, it is suggested to apply "mono commercial" theory and "Piercing the Corporate Veil" system for a parent company and its closely related company.

[7] Beate Sjåfjell: Environmental Piercing of the Corporate Veil : The Norwegian Supreme Court Decision in the Hempel Case, European Company Law, Vol. 7, pp. 154-160, 2010.

[8] The Pollution Control Act Section 51 sets out that "anyone that possesses, does, or initiates anything that results in or that there is reason to believe may result in pollution to arrange or pay for any investigations or similar measures". In the case of Hempel, however, the core issue is whether the parent company shall bear damage liability for environmental infringement by its subsidiary, especially when such infringement happens before the parent company purchases the subsidiary. In fact, the key is whether a parent company shall bear liability for the fault of its subsidiary when the parent company itself has no fault. 